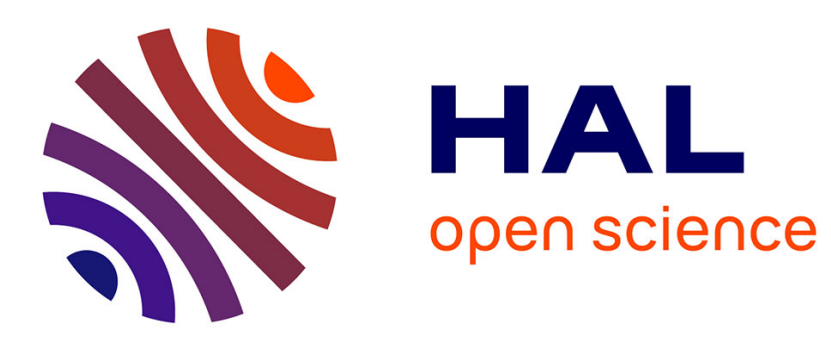

\title{
The local enactment of Hindutva Writing stories on local gods in Himachal Pradesh
}

Daniela Berti

\section{To cite this version:}

Daniela Berti. The local enactment of Hindutva Writing stories on local gods in Himachal Pradesh. Cultural Entrenchment of Hindutva. Local Mediations and Forms of Resistance, Routledge, pp.64-90, 2011, 978-0-415-67799-8. halshs-02173325

\section{HAL Id: halshs-02173325 https://shs.hal.science/halshs-02173325}

Submitted on 4 Jul 2019

HAL is a multi-disciplinary open access archive for the deposit and dissemination of scientific research documents, whether they are published or not. The documents may come from teaching and research institutions in France or abroad, or from public or private research centers.
L'archive ouverte pluridisciplinaire HAL, est destinée au dépôt et à la diffusion de documents scientifiques de niveau recherche, publiés ou non, émanant des établissements d'enseignement et de recherche français ou étrangers, des laboratoires publics ou privés. 
[Published in D. Berti, N. Jaoul, P. Kanungo (eds.) Cultural Entrenchment of Hindutva. Local Mediations and Forms of Resistance, Delhi, Manohar, 2011] pp.64-9

\title{
The local enactment of Hindutva Writing stories on local gods in Himachal Pradesh
}

\author{
Daniela Berti
}

This article sets out to examine how an RSS-affiliated organisation aimed at rewriting Indian history implements its cultural programme at a local level through the participation of people who do not necessarily have any connection with the Hindutva ideology. Though the capacity of the Hindutva programmes to penetrate different milieus is often evoked in Hindutva studies, the reasons behind this process are rarely explored. Jaffrelot (2005) touched upon this point briefly in a joint volume dedicated to the internal functioning of some of the main Sangh Parivar organisations. The author notes how the principle according to which RSS cadres have to focus on the specific issue or 'cause' the organization was created for, finally ended up giving them considerable autonomy -which would explain the internal differences between the Sangh Parivar organisations. The author argues that these internal differences are in fact strategically put to the fore by Sangh Parivar leaders in order to attract support "from many different - even antagonist- quarters of society". (op.cit.: 16, my emphasis).

While Jaffrelot's analysis focuses on politically committed actors (pracharaks or highranking RSS leaders), I will take here a more bottom-up perspective and I will consider the Hindutva local network at its grassroots level. In fact, a number of RSS cultural programmes are carried out at regional level by what will be defined here as "local mediators". These are people who belong to local society and to different social milieus, and who agree to become involved in an RSS organisation by implementing specific cultural projects that they considered to be "useful" at local level. The analysis presented here will thus shift attention from national representatives to regional mediators, whose involvement in the Hindutva programme is often due more to a cultural motivation than to any ideological or political commitment. The multiplicity of the mediators involved in running these cultural projects at local level are also at the root of the way in which Hindutva takes different forms and meanings according to specific local and regional dynamics. The non homogeneity of Hindutva is now well established among academic scholars. As Ludden (2005: xiv) points out, not only does 'Hindutva [have] many histories, and maybe as many meanings as locations' but, even in the same region, it may assume different meanings according to the different organisations which may be simultaneously active in a region. ${ }^{1}$

The focus here is the case of the Akhil Bharatiya Itihas Sankalan Yojana ('The Plan for the Compilation of History of the Whole of India' - hereafter ABISY), one of the main promoters of the Hindutva discourse on Indian history. Founded in the 1970s by the RSS pracharak, Moropant Pingle, the organisation has its central office in Jhandewalan - the Delhi RSS

\footnotetext{
${ }^{1}$ On the cleavages between the RSS affiliated organisations see Jaffrelot, 2005.
} 
headquarters. This centre is linked to a leader, Thakur Ram Singh, a 93-year-old man who has dedicated his life to invoking and propagating Hindu nationalistic feelings. At its central level, ABISY leaders support and propagate all Hindutva theoretical presuppositions which have been denounced by many academic historians as ideologically biased. Although the organisation shares the same views of history as Vidhya Bharati, another RSS affiliate, it is not directly involved in the revision of school textbooks. Since the 1970s ABISY has created branches throughout the country with the specific aim of collecting and writing history on a very small-scale, i.e. a district, a town, a village, and to analyse this data in publications which address a wide range of audience.

This paper will specifically focus on the way ABISY's national programme has been implemented in the district of Kullu (Himachal Pradesh) and has been adapted to Kullu's cultural specificity. In this region ABISY's local leaders have considered the "Aryan issue" i.e. the idea that local culture is the cradle of Vedic and Aryan culture ${ }^{2}$ - as the potential element for involving local people in its "cultural activism". I will show how this burning issue, which has been provoking a concerted and vigorous reaction amongst many Indian and Western historians, 'fits in well' with the cultural and geographical context of Kullu, and what form it takes in this specific region.

In the first part of the article I highlight the contrast between the Hindutva-oriented position the ABISY defends as far as its central leaders are concerned and the field-oriented directives given to its local mediators for small-scale data collection. I show how ABISY's field-work methodology is what gives the organisation credibility among the local population. I then focus on the activity that the organisation runs has in Kullu, and on its local mediators how these are selected and why they may (or may not) be persuaded to become involved in the ABISY cultural project. Finally, the analysis will show the peculiar way in which the ABISY's ideological vision of Indian history infiltrates local conceptions of Kullu history, how it melts and becomes mixed up with pre-existent conceptions and how it encounters local forms of resistance.

\section{National programme and local directive: 'Desh Nirdes'}

Among the criticisms that academic writers make of Hindutva historiography is the religious or ideologically-oriented character of their theories as opposed to a "meticulous, strongly data-based approach" (Cf. Witzel 2005, Thapar 1999). However, the first thing that local people point out when asked about the cultural activity of the ABISY organisation in their region is precisely its systematic and field-oriented activity of data collection. In order to grasp this difference between the academic position and popular perception of ABISY, two different levels of actors and activities have to be considered within the organisation's national network.

Those who belong to the ABISY central board are personally committed not only to ABISY, but also to RSS, and their activities within the organisation are strongly involved in pursuing the general long-term Hindutva programme of reforming the whole society. The publisher of these works is the ABISY itself, Jhandewalan in Delhi (the RSS headquarters) and are written by Hindutva committed professional historians or non-academic scholars. The titles of these publications show how these writers' concerns are in line with the mainstream Hindutva view of Indian history: Discovery of Source of Vedic Saraswati in the Himalayas by V.M.K. Puri (2004), a glaciologist who was formerly appointed to the Geological Survey of India in

\footnotetext{
${ }^{2}$ This Aryan past, common to all "Hindus", is thought to have been passed down in Vedic, Puranic or epic texts. The characters and events described in the Sanskrit epics, considered by these authors to be "history", are particularly used and reinterpreted in order to represent India's past.
} 
Lucknow; or Vedic Culture and its Continuity: New Paradigm and Dimensions published by Shivaji Singh (2003), former head of the Department of Ancient History, Archaeology and Culture of Gorakhpur University and at present ABISY's national president. These volumes are rather technical and speculative, and do not circulate beyond ABISY's literate members.

Apart from these national-level projects, which ABISY has in common with other Hindutva organisations, the specific aim of ABISY is to elaborate small-scale projects concerning regional, district, block and town levels - which is how ABISY's different 'units are called. These are coordinated by local people who do not necessarily belong to Hindutva circles. The person in charge of the project (for a district or a town), in consultation with ABISY central leaders, decides which topic the project has to focus on. As one ABISY leader explained, these projects must focus on what is perceived to be the main specificity of local culture likely to rouse people's feelings and motivations.

Each district has indeed its own specific project. For example, in the town of Chandigarh (in Punjab), there is a project on 23 'historical sites' situated in an area 'covering 40 to $50 \mathrm{~km}$ around Chandigarh, [where] the team discovered that the residents are sitting on 5,000 years of history' (The Tribune, 18 Sept. 2005). This will allow them to find an ancient Aryan-Hindu substratum to a recent, foreign urban construction. In the district of Kangra, south-east of Himachal Pradesh, the unit's project deals with Trigarta, an ancient name for this area. One ABISY publication entitled Yug-yugin trigarta ('Trigarta through the ages') translates Trigarta as 'three valleys' which, as explained in the foreword, would correspond to a 'distinct socio-cultural and political entity, [whose] history goes back to before Mahabharata' (Gupta 2001: 2). In Kullu district (central Himachal) the project specifically focuses on village deities (devi-devta) and the place they occupy in the regional past. This is indeed how villagers associate themselves with their past, and it is therefore supposedly the topic which would interest everybody in Kullu and make them keen to become involved. ${ }^{3}$ What is underlined in the project is not only collecting and recording first-hand material on local deities, but also discovering and showing their 'forgotten' Vedic, Puranic or epic origin.

Central leaders provide those who wish to collaborate on this project with "manuals of instructions" giving practical suggestions on how to collect data in an exhaustive and systematic way. In Kullu, the manual which was commonly circulating among ABISY people was Nisha Nirdes ("guidelines"). This is a manual written by the organization's Committee (Shri Baba Saheb Apte smarak samiti c.1990). It gives very practical suggestions on how to collect data in an exhaustive and systematic way. The mere fact of supplying a manual to instruct people on how to collect field material appeared to ABISY collaborators to be proof of the up-to-date and well-organised character of the programme. This ABISY manifesto sets

\footnotetext{
${ }^{3}$ Another point that may be noted is the choice made by the ABISY Kullu branch to focus on village deities rather than on a figure like the royal god Raghunath (a name for Vishnu), a god on behalf of whom the Kullu kings ruled. This comes into contrast indeed with what Kanungo (2003: 3294) observed on the Hindutva cultural activity in Orissa. Here what has been perceived by the RSS as a 'crucial unifying element' through which panIndian nationalistic culture could be transmitted is the god Jagannath, a Vishnu incarnation who since the 12th century has been made 'the king of Orissa'. Similarly to what happens in the case of Raghunath, throughout different historical periods the god Jagannath remained 'a potent rallying symbol, reinforcing the collective regional and ethnic identity of the territorially fragmented Orissa'. According to Kanungo, the RSS's project in Orissa is thus to 'channel the devotional and spiritual energy of the Oriya towards the Hindu Rashtra' (ibid.: 3297). There may be reasons why in Kullu Raghunath has not been perceived as having the same Hindutva pertinence than Jagannath. It is above all the fact that Raghunath has always been identified as the personal god of the king. The relations that villagers have with him are quite distant and formal, and have nothing to do with the emotional and devotional feelings they have with village deities. We may imagine, moreover, that a different choice would have be made if ABISY leaders came from outside -as the pracharak were in Orissa- and not, as is the case, people rooted in local culture like Vidhya Chand Thakur or Davendar Singh.
} 
out information about the organisation's aims, schedule, and methodology. It addresses those coordinating the project at local level to advise them on what procedures to follow. I will analyse some of these guidelines in order to throw light on how the ABISY programme is presented.

In the manual, some notions of the Hindutva theoretical speculations on history are sporadically evoked. For example, the idea of collecting data over a period of 5,000 years according to an Indian system of calculating time (bhartiya kal ganna), which is considered to be scientific, as opposed to the Western system of calculation, based on Christianity. This data collection -so the manual points out- should cover "every part of human life" and information must be grouped into (geographical, religious, social, political, economic) topics, which will be written up by various writers. This multifaceted approach to history, although similar to a British Gazetteer, is presented as opposed to the "Western vision of history" which would be based -as the Hindutva discourse commonly goes- "on war facts and royal genealogies". (Shri Baba Saheb Apte Smarak Samiti, c. 1990: 5).

A crucial point put forward in different passages of the manual is the need to involve local people in data collection.

'Local people have more information about the customs and the traditions of their own area and they can acquire material more easily than outside people. They can understand and choose the material according to the milieu. This type of collection will be much more reliable than work done by people from outside' (op. cit.: 6).

The involvement of local people in these different regional projects is in keeping with the aim of extending regional history writing to non-professional historians. This is a very important item on the ABISY agenda, which is announced in the manual. A distinction is made between so-called "common men" whose task would be to collect information on such subjects "as local traditions, festivals, geography", and "trained people" who would work on projects which are of interest at national level. ${ }^{4}$

In addition to data collection, ABISY requests its local workers to publish them. The manual provides detailed indications on how to edit, publish and distribute all this material while specifying that "at the beginning of each subject there should be a sub-subject"; that "mention should be given of how many words the articles should contain"; that "publications should be made available upon purchase" and other similar indications.

These kinds of data-based publications are published under the name Bhartiya Itihas Sankalan Samiti, the name that the ABISY uses at regional level. A member of the Himachal Pradesh branch of the organisation defined these local publications as "real books", containing more rough material than what he called "research books", in which these so-called "rough data" were analysed in a more speculative way. (Vidhya Chand Thakur, interview).

\footnotetext{
4 These projects are enumerated for example in one of ABISY's manifestos entitled ABISY. Concept and Working they also present the projects 1) a project on how the Indian calculate time (bhartiya kal ganna) which is considered to be scientific as opposed to the Western calendar, based on Christian religion; 2) a project on the Sarasvati river which would show the existence of the Vedic river using modern scientific techniques (such as Nasa satellite photographs); a project on the Mahabharata war, supposed to precede the kali yuga by 36 years, thus being 'the Sheet anchor of Hindu history'. Other projects deal with 'The Date of Birth of Buddha', 'Is Samdrokottus Chandragupt Maurya?' or 'History of Ancient Cities through the Ages'. In another ABISY brochure 25 projects of 'general interest' are mentioned, most of which are on 'distortions': 'distortion of Indian literature and languages', 'distortion of Indian chronology', 'distortion in modern education', with even one on the 'distortion of Indian nationalism'.
} 
We will see how these kinds of methodological instructions are implemented at local level in the region of Kullu in Himachal Pradesh. I will show how the organisation works by creating a network of intermediaries operating in the different 'units'. 


\section{ABISY's local mediations}

ABISY's organisational structure includes a multiplicity of roles which are assigned to people with a different kind of profile. Three important ABISY figures at central level are RSS pracharaks: Baba Saheb Apte, in memory of whom the organisation was created; Morupant Pingle, who founded ABISY in 1973; and Thakur Ram Singh, former national president and still considered to be crucial in "guiding" the organisation ${ }^{5}$. Over recent years, the role of president has been attributed to academic historians. Two examples are Thakur Prasad Verma, a retired professor of Benares Hindu University, and Shivaji Singh, from the University of Gorakhpur. Pracharaks and academics share the same visions of history, yet whereas the former focus more on the organisational aspects related to the implementation and visibility of the programme on the national territory, academics focus more on their research, writings and publications. The national committee also includes a number of other positions, such as vicepresident, secretary, treasurer, and so forth.

A similar structure is repeated at lower levels of the organisation - from "kshetra units" (each grouping together different states) to state, district, block, town units and sometimes even village units. Thakur Ram Singh used to talk of all these units presenting them somehow in terms of conquests: 'We got 350 out of 832 districts [...] we got 6 out of 11 provinces [...] we've got about 900 historians and we've got 6 full-time historians devoted to this'. On paper, some of these units are only branches, "empty offices" -as Thakur Ram Singh himself admitted. Insisting on the long-term character of the project, what was of importance to him was "to create a background, a fundament? (structure)"."It is a long-term project. It may take many centuries?" - he repeated many times. (interview 2004 Delhi RSS campus, Jhandewala).

A local unit is officially created by selecting a president, a vice-president, a secretary, a vice-secretary and a treasurer, etc. - it therefore involves the formation of a micro-circle of local ABISY intermediaries, from where the branch's activity can be launched. The decision to create a unit and the selection of the appointed persons is made on the initiative of the central leaders in consultation with a local network of contacts. Those appointed to these positions do not have to be from the RSS or to be politically engaged. One requisite may be to have written something on regional history and traditions or to be at least personally interested in promoting and coordinating a cultural project.

One example of these profiles is that of Vidhya Chand Thakur, former secretary to the Academy of Art, Culture and Language in Shimla (the state capital). Vidhya Chand, who lives in the Kullu countryside, has not been influenced by the RSS way of life. He does not attend the local shaka, the training camps, and he only came to know about the ABISY quite recently, in fact in 1990. At the time he was working for a language department and he was invited to an ABISY meeting when Thakur Ram Singh (the Delhi leader) was giving a seminar in the region.

... I attended the meeting and I listened to Thakur Ram Sing's (the Delhi leader) opening speech. That speech attracted my attention. His topic concerned the fact that Aryans were the real inhabitants of India and he presented it so logically that he really did impress me. Before then, I was convinced that we came from Central Asia (laughing). Central Asia was upmost in our minds. He made his point that we are real inhabitants of here [India] in such a logical way and explained why the concept that we came from outside was made up by English historians to dampen people's morale. He said for example 'check before 1866 that there was no mention that Aryans came from outside. It was all made up after then because they wanted to rule over us"'.

\footnotetext{
${ }^{5}$ For more details about this organization at its central level see Berti 2007b.
} 
After listening to this speech he approached Thakur Ram Singh, who immediately made him district president. After a few years, he was transferred to the Shimla academy, and made ABISY general secretary for the whole of Himachal Pradesh.

Vidhya Chand is not just an organizer. He is also author of several articles on regional culture. In 2003 he coordinated a volume on the Ramayana, where he showed how a number of stories commonly heard in the region are nothing but versions of the Valmiki's epic. Although the search for a homogenous basis for cultural diversities has brought his views into line with the common Hindutva discourse, there are also other elements that make his discourse more complex. On many occasions, Vidhya Chand has underlined the fact that this should not be done to the detriment of individual regional cultures. For him, local stories and customs have their own history (itihas) and any link with this history must be maintained. He set this local ABISY approach against the more radical and intolerant activity of the VHP also active in the area. In his words 'our [ABISY] approach to local history tries to preserve the original form. Local history -he told me- should not be "Sanskritised"6.

"Our national body has given its representatives at district or village level some instructions, whereby history should be collected from "known to unknown"?. Our culture is basically one. In the root-points our customs are the same throughout India. [...] for instance, there are some gods here who have local names but who correspond to gods whose names are in our Sanskrit epics. Nevertheless, there are many local names which have in themselves their own history. If we add to this local name a Sanskrit name we lose the links this name has with history. Thus our approach to local history tries to preserve this name in its original form. We must not sanskritize the original name... If you discover vedic names how you will reach this up to grass root?." (Vidhya Chand Thakur, interview, 2004)

By referring to the volume Disha Nirdes ("guidelines") mentioned above he emphasized the difference between the two levels of ABISY activities and the need to distinguish the "first process of data collection" from the "next stage, which is the ideological part". He explained to me, "what we request to those who want to collaborate on our project is that whatever you know, either of Veda or Purana, do not ask those you are questioning anything. Just write down whatever they say about local traditions or whatever is in front of you ". He justified this pragmatic approach to data, bearing in mind the urgency in preserving information "that is rapidly going to vanish because of the transformations taking place in the modern world". He opposed local traditions to Vedas and Puranas literature which "is already published worldwide". Thus, for him, the work of connecting local traditions to ancient texts was not presented as the real priority. (Vidhya Chand, interview 2004)

This kind of affirmation may partly be a rhetorical statement, especially if we consider some of Vidhya Chand Thakur's articles where he lays particular emphasis on interpreting local culture in terms of a 'Vedic' or 'pan-Indian' framework. But they may also correspond to a real feeling, if we consider the fact that ABISY people acting locally in Kullu, such as Vidhya Chand Thakur, belong to local society themselves and are attached to regional practices. As a matter of fact, Vidhya Chand Thakur's idea that Vedic and local traditions are strictly interlinked coexisted with his emotional attachment to his local cultural identity. The arguments he used to show this link were not always the same as those generally put forward by mainstream Hindutva, whose effort is rather to promote a "cleaner" and more "purified" Hinduism. One of these arguments concerned, for example, the rather widespread local practice of animal sacrifices which, instead of being condemned, was put forward to prove the

\footnotetext{
${ }^{6}$ This word is quite commonly used in the region. In Vidhya Chand Thakur's discourse however the idea is that local name should not be change into Sanskrit names since local names contain like the traces of the ancient past which allow the "Vedic identity of the god" to comes out (to be disclosed)
} 
Vedic character of the Himachali culture. Vidhya Chand Thakur opposed the view that animal sacrifices were widely accepted in the Vedas with the mainstream Hindutva attitude, whereby animal sacrifices are considered to be avedic. This contrasts with other members of the local elite in the same region, some of whom are Brahmins, who consider such local practices as unduly violent or "superstitious" and advocate a more spiritual, "purified" Hinduism. At the same time, though the latter views may seem to be more akin to the ones promoted by Hindutva, this elite insists that their own idea about what it means to be a Hindu is very different, and should be clearly distinguished from the one proposed by Sangh Parivar activists.

Another important leader of the ABISY's local branch is Davendar Singh, the eldest son of the present Kullu raja, who in 1999 was appointed president of the Kullu ABISY. Davendar Singh's profile was ideal for coordinating the aforementioned project on local deities. On the one hand, his father and paternal uncle are BJP leaders, which meant that a lot of people were ready to collaborate with him. Then, as the king's son, he is considered to be close to the local deities due to the strong ritual and political ties that his family had in the past and continues to have with these deities and with villagers in charge of their cult. This grants him a certain authority in going from village to village and asking ritual specialists about stories about village gods. During the first seminar held in Kullu in 1998, Davendar Singh and other local ABISY members revealed how they wanted to proceed. Their project was to ask village people and especially ritual specialists directly to collect, record and write everything concerning these village deities. This includes a local repertory of gods' stories called bhartha. These are said to be revealed by the deities themselves who, when speaking in the first person through their institutional mediums, recount the episodes in their life: where they come from, how they came to settle in their temple, what relationships they established with the local kings, and so on. The particularity of these bhartha is that they are presented by local people as secret (cfr. Berti 2006). Most of them are recited by the medium with only the priest present and using 'god's language', which makes them difficult to understand. And even in the rare cases where the recitation is performed publicly, they are recited in a very low voice that nobody can hear.

During the seminar, Davendar Singh stressed the importance of giving a written support to the content of these stories which, according to him, would contribute to throwing light on India's past.

He formally requested village priests and mediums who have access to these "secret" performances, to help collect their respective god's bhartha and to write it down on paper, even if they do not understand its exact meaning. As he explained during his speech at the seminar, the work of "ABISY scholars" would be "to decipher" these bhartha (often just some snippets of them), and to reveal their similarity with Sanskrit texts, by focalising on specific words or expressions. This would reveal the Sanskrit identity of the village gods. For example, the bhartha of Katrusi Narayan Bhalayan of the Tarapur region is said to correspond to a passage from the Bhagvat Dasham Skanda, which allows them to identify this god with the ('pan-Indian') god Skanda. The fact that the bhartha is recited not by an erudite Brahman who knows Sanskrit, but by an illiterate and low-caste medium was presented as proof that it is directly recited by the god. In this ABISY project the bhartha represents the original source as well as proof (praman) of the deity, for the very reason that it is revealed by the deity itself. In this sense, they consider the bhartha similar to the Vedas which, being revealed knowledge, are supposed to be a discourse of "truth" par excellence (Malamoud 1989). Moreover, the fact that bhartha are pronounced in a secret or metaphorical language, only decipherable by ritual specialists, bestows on the latter special authority in proposing different 
kinds of parallel between, not only the bhartha and the Vedas but also -and consequentlybetween bhartha and science. ABISY's discourse is here similar to the general claim among Hindu nationalists that "Hinduism is simply another name for scientific thinking" and that the Vedas converge "with the contents and methods of modern science" (criticism in Meera Nanda 2003:65).

Let us take the example of Atthara Kardu [lit. Eighteen Baskets] which are the object of many seminars held in the district. According to a local myth, Atthara kardu are eighteen godsnakes who lived inside a jug in Goshal village and received puja every day by a local priest. One day the puja's light fell over inside the jug causing a fire which drove the snakes out so that they ran here and there in different villages where they are still now living. This local myth is not really taken into account by ABISY committed scholars. Instead, they base their theories on the Atthara kardu's bhartha. At the Kullu seminar this bhartha was presented by Bhagat Ram, an ABISY active member, as follows:

There was obscurity. The world was full of water. We fell from the sky, and grew up on the earth. We made the earth, made Man. Made from gold, could not speak, made from silver could not speak, made from copper could not speak, made from god's dirt then he was able to speak. From one we became two. From two ten. From ten hundreds and from hundreds many thousands and from thousands the earth was filled.

ABISY's writers claim (without giving further details) that these passages from the bhartha have to be placed in relation to the Sanskrit "Ganapati story" which would show how they are "Vedic gods, like Indra, Rudra, Soma who came to be by Vishnu's power when he was lying on the Shesh nag's body in the ocean" (Bhagat Ram 1999).

The same passages from Atthara kardu's bhartha are then said to correspond to something that has also been proved by geologists' findings:

According to geologists, when the earths temperature rose a thick mass of snow melted, the earth turned into water and creation came to an end. Then the water level dropped and a new creation came about. Atthara kardu entered the body of Manu [the first man] and made the model for the development of mankind...(ibid.)

Hence a local "secret form" of the gods' story is used here as proof -self-revealed but also "scientific"- for building a national "Hindu conscience" at regional level. Moreover, the result is that the gods' bharthas are deprived of their "secret" character by those who saw in their secrecy the very condition for their authenticity.

Although Davendar Singh is convinced of the Aryan-Vedik strata of Kullu village deities and presents the ABISY's approach as an important task "to preserve the authenticity of local culture", he is not personally involved in this kind of speculation. He does not consider himself an ABISY scholar, nor does he personally theorize about this topic as Vidhya Chand Thakur does. He considers himself rather as a 'man on the field', who spends time going from village to village, talking with people, and collecting first-hand information. As a matter of fact, Davendar Singh is rather an emblematic and locally renowned figure whose task was to attract a network of people ready to help him in collecting material on local deities. He is also a fervent devotee of local deities and emotionally involved in their village cult. From his point of view, being the king's son, he feels directly concerned by the idea of including Kullu local deities in a nationwide project. 


\section{Local gods versus Vedic Rishi}

The first project finalised by the Kullu unit since Davendar Singh was elected president has focused on rishis - i.e. local deities who are included in the same general category of village deities (devi-devta) but who are in fact identified as Vedic rishis. ${ }^{7}$ Davendar Singh, in his capacity as ABISY president, sent a letter to many village temple committees to invite people to pool together their resources in collecting data. The content of this letter illustrates the kind of argument used to encourage people to collaborate.

\section{'Respected Sir,}

As you know, this holy place of Kullu is a place for rishis-munis [...] This part of Kullu culture is an invaluable heritage of humanity and national culture. Today the passing of time has also affected our gods' traditions for future generations. For this reason, the Indian History Collection Committee has decided to collect information related to devis devtas [...]. Along with this programme, a letter has been forwarded to you, since this important work cannot be completed without the cooperation of those people involved in gods' beliefs. So with regards the work related to gods (god-work), I require your co-operation. Not only do I hope, but I am totally confident that you will join in this god-work with total conviction and will give your full cooperation and blessing to make this project successful. I must explain that whatever material you send, the committee will mention your co-operation'.

The result of the rishi project was published in a volume under the title Kullu ki rishi parampara, under the Bhartiya Itihas Sankalan Samiti (the ABISY' regional name) copyright in 2005 and edited by Surat Thakur (2005), another active member of the local ABISY. In his preface Davendar Singh focuses on 1) the fact that it has been proven (sampraman siddh hoti $h e)$ that Vedic rishis have been wandering through the Himalayas, and that knowledge of their history in relation to the region will contribute to national history; 2) the need to collect traditions which are likely to die out - a concern often expressed by ABISY members; 3 ) the method of collecting first-hand material by going out into the field: the importance of having reliable informants, of checking different points of view among informants, of discussing these data during regular seminars, and so on.

The volume is in fact a collection of 34 articles written by different people. During my fieldwork, I met most of these contributors and I became aware that the majority of them were neither concerned with RSS ideology nor with the ABISY national project. Many of them were temple specialists or administrators, who simply put into writing what they knew about village deities and temple traditions without bothering whatsoever about ABISY ideological affiliation. Others held a more ambiguous position. This was the case of Hira Lal Thakur, a convinced Gandhian, and director of the Khadi centre in Kullu. In his office full of Gandhi portraits, he drew a parallel between RSS ideology and the Gandhi 'svaraj' ${ }^{8}$. Although he declared that he was not concerned with RSS programmes and its purpose, he was firmly convinced that ABISY was doing 'constructive and true work whose aim is to deepen our knowledge of the history of Kullu deities'.

The 34 authors of the book are the more visible part of the group of ABISY collaborators. A wide network of village data collectors has been built by Davendar Singh, and their individual work is acknowledged in the preface to the book. One of the more invisible intermediaries is Rajan Seluria, a man who runs a business near the Kullu Royal Palace. His office is constantly visited by village people who come to him to have their wool cleaned or to have oil pressed from mustard seeds. He also recently set up an annex where people come to

\footnotetext{
${ }^{7}$ On the importance of rishi in Hindutva rethoric see Rajagopal (2001).

${ }^{8}$ The idea of an appropriation or incorporation of Gandhian idioms into Hindu nationalism, and in particular the idea of Deendayal Upadhyaya's 'Integral Humanism' has been developed by Hansen (1999: 84-86). See also Zavos 2000 .
} 
be cured by snake bites. He explained to me what he knew about ABISY and what his role was:

\begin{abstract}
'ABISY is based on village deities. They want to collect deities' traditions and customs [...]. We help Davendar gather all this information and give it to him. He puts it into form and takes out some good material....When a villager comes to my office to have his wool cleaned or other work done, he has to wait so we start chatting. I just listen to what he says without taking notes to keep him talking. Afterwards, I write down what he said to me and keep the paper in my drawer. Then, when I have gathered enough material I give it to Davendar Singh [...] Davendar Singh told me to collect material. He and I are very close. He told me that I have to write this book and I need material. I said why not? I will help you [...]. He also told me to verify that what people say to me is true or not by asking different people and by crosschecking their replies. Moreover, I talk with those people I know will not lie, who will speak their minds'.
\end{abstract}

Due to the presence of these mediators, the RSS programme may have a completely different effect than the one anticipated by ideologues at national level. In fact, by leafing through the volume, what immediately stands out is the difference between those authors who are clearly involved in Hindutva ideology, such as Vidhya Chand Thakur, and those who are not. In the articles written by ABISY leaders, reference to the textual equivalence of the god is systematically evoked along with his local identity. In some cases, the textual reference is introduced directly by quoting a few passages from a Sanskrit text. By contrast, in the remaining articles, the only reference to a textual identity of the god is in the title, yet no reference is made to the textual traditions. What is reported here is just the local story of the god as well as the practices followed in its temple, similar to a detailed ethnographical report.

Including articles with no pan-Indian reference at all in the volume may appear somewhat incongruent, given the central idea behind the project of discovering a pan-Indian basis for local culture. But in fact, ABISY leaders do not seem bothered about this. On the one hand, people like Vidhya Chand Thakur or Davendar Singh are manifestly convinced that local traditions should be maintained since everybody in Kullu is 'emotionally attached to them'. On the other hand, when a village god is included in a book whose aim is explicitly announced in the preface - 'to find out about Vedic rishi'- any god whose story is included in the volume is supposed de facto to be a Vedic rishi. Moreover, the simple fact of including all these village gods in a volume published under the ABISY name, moves the programme forward and increases the visibility of the organisation. As Dayanand Sharma, a Kullu Brahman, rather critical about Hindutva, explains: 'During seminars they gather people to discuss a topic they feel concerned about, the main leaders give their speeches ....somehow they introduce a feeling of national unity.'

\title{
Convergent stories
}

The two main ideas behind the ABISY project in Kullu -i.e. mixing history with local mythology, or searching for a 'pan-Indian' equivalence to local gods- are in fact commonly shared by most people in Kullu, independent of their ideological and political affiliation. If we consider most of the local publications that started to appear during the 1970s, the "history" of the Kullu region is presented as being completely melted down with the stories of its local deities. A comparison is also commonly made by local writers (and before them by British writers) between local stories and Sanskrit references. One example is that of Lal Chand Prarthi, a local leader from the Congress Party and one of the first Kullu authors. Prarthi 
insisted in all his works on the specificity of Kullu culture, yet at the same time he constantly tried to show its pan-Indian substratum.

'The name of the ancient land of Kullu can be traced back to the hoary past and there are several
references to it in the Ramayana, the Mahabharata, Vishnu Purana etc. .... There are quite a few
significant legends connected with the Ramayana. It was the privilege of a Rishi from the
valley, called Shringa rishi, who had his ashrama near Banjar (a local area) to act as the purohit
at the 'Putreshti yajna' of Raja Dashratha as a result of which the great Rama was born....The
valley came into being through a number of events and incidents believed to be associated with
it during the Mahabharata. The Pandavas, it is said, visited this valley as many as three times'
(Prarthi 1970).

The affinity between previous ideas on regional culture and the Kullu ABISY project was addressed during the first seminar held in Kullu in 1999 when Vidhya Chand Thakur underlined that "the reinterpretation of local tradition in the light of Vedas, Puranas and Epics is not new and it is not specific to the Kullu region but it is a national phenomenon" (Vidhya Chand Thakur, 1999). He also supported his argumentations by relying on British authors who were also concerned with finding a Sanskrit equivalence to local deities.

In spite of the convergence that some local writers may have with Hindutva's vision of history, some of them have adopted a critical stance and do not want their work to be assimilated with this association's programme. Their criticism, however, does not take the secularist tone of most academic historians and it is never explicitly expressed in such terms. By contrast, it is by talking with these local authors that the difference between their view and the Hindutva discourse comes to light more clearly.

One example is that of Molu Ram Thakur, author of many publications in Hindi and English on different aspects of Kullu culture. He is not strictly speaking an academic, although he is often associated with Shimla academic circles. ${ }^{9}$ From a political point of view, Molu Ram Thakur does not pursue the same ideological orientation as Vidhya Chand Thakur. Everybody in Kullu knows him as being rather a Congress Party sympathiser. However, as far as his publications are concerned, he has no explicit position to defend. What is important to him is as he says- 'the study of local traditions in a non ideological way'. However, in 2000, Molu Ram Thakur published a book entitled Vaidik-Arya and Himachal, Historical and Research Account where he defends the thesis according to which Aryans did not come from outside, but were the original inhabitants of India and he shows how to prove this by taking Himachal Pradesh as an example.

Though supporting ABISY's (and Hindutva's) central idea, he denies any involvement in Hindutva ideology - and everybody in Kullu agrees on this point. He has also always refused to be a member of ABISY, and he defines himself as merely an 'adviser'. What he wants, he says, is to be sure that what he calls 'Hindutva type' authors will not 'corrupt the tradition', or 'saffronise deities' local stories'. Notwithstanding his criticism of Hindutva, Molu Ram Thakur approves the Kullu ABISY project as far as data collection is concerned:

'ABISY people are not going about it in the right way except for the first phase (of their project), that is, the collection of different deities' stories. I agree with their method of work but

\footnotetext{
${ }^{9}$ He has, for example, contributed to a volume published by Laxshmi Thakur (M.R. Thakur 2002) of the Shimla's Institute of Advanced Study which circulates in all international libraries.
} 
not with the results they obtain. [...] The RSS no doubt has its idea and its version (of history); but ancient material has been collected by them and as an adviser I don't want this material to be spoilt in any way. My idea is that they need to analyse it correctly, without interpreting it in their own way. [...] The first thing we do is to collect and edit the historical background of each deity. The deities' culture should not be corrupted. I could not tolerate that! If ever they write anything according to their own point of view, I will be up in arms.'

When someone, such as Molu Ram Thakur, talks about the "saffronisation of local deities" what he criticises is not the idea of looking for a Vedic and pan-Indian substratum of local tradition -since he has also made reference many times to Vedas in his books or articles on Himachali culture. It is more the fact that this is done in a systematic and biased way for all local deities.

This is a very important nuance which it is crucial to understand if one is to grasp the sometimes very subtle difference between those who accept Hindutva and those who criticise it. Indeed, it shows the local shape that resistance against Hindutva historiography may take.

In order to give a better idea of this nuanced but relevant difference, I will take as an example the debate that opposes Molu Ram to Vidhya Chand Thakur regarding the identity of Jamlu devta, a well-known regional deity whose temple may be found in different villages of the district. According to Vidhya Chand, in all these cases Jamlu deity may be identified with Vedic rishi Jamdagni. Molu Ram disagrees arguing that only some of these Jamlus are Jamdagni whereas others are not. He considers that Vidhya Chand defended this idea in order to favour his ideological vision of the past. 'Try to ask him [Vidhya Chand] how he can argue, from a linguistic point of view, that Jamlu comes from Jamdagni !' -he once told me."

The nuance which sets these two positions apart is indeed even further complicated when delving deeper into their debate. In fact, for Molu Ram Thakur, these Jamlu gods, who are not Jamdagni rishi, are not 'local gods' for him either -they are not 'simply' Jamlu gods. They are indeed representatives of the god Yama (the god of death), who is also a pan-Indian god of the textual repertory. He gives the reason for this hypothesis in his articles (cf. Thakur, 2002). Now, this hypothesis is contested by Jamlu's devotees who honour these asaid Jamlu-Yama because, although Yama is a Vedic and pan-Indian god, they do not want their god to be associated with the god of death! By contrast, these very villagers were extremely pleased and proud to see their god Jamlu associated with Jamdagni rishi.

Here again a distinction has to be made in order to avoid the risk of confounding attitudes which are in fact extremely different. The acceptance by Jamlu devotees of the 'Jamdagni rishi equivalence' of their god is not due to the same 'nationalistic' reasons behind Vidhya Chand's statements that all Jamlu are Jamdagni. As it happens, they are both saying the same thing, but not for the same reasons. While Vidhya Chand's search for the Ramayan substrate of local stories may go along with the discourse on cultural unity, for other members of local society, cultural or nationalistic unity is not their problem. The issue of the greatest concern for them is to have their local god's importance recognised, and for him to somehow acquire greater prestige (cfr. Berti 2007a).

The example mentioned about Jamlu shows at least three different motivations behind the search for an equivalence between the textual repertory and the local deities' names or stories. For common villagers, this textual equivalence is just a means of valorising and attributing prestige to their own local deity in relation to neighbouring ones. For Molu Ram Thakur, it is more the outcome of his erudition and of his folkloristic approach, inspired by the works of Orientalists and of British administrators. For Vidhya Chand Thakur, the folkloristic approach partly combines with his engagement as an ABISY member. However, what is common to both villagers and writers like Molu Ram Thakur or Vidhya Chand Thakur is not so much the idea of "globalising the local", as is often observed for Hindutva organisations elsewhere, but 
rather of "localising globality" (Harneit-Sievers, 2002), an attempt to highlight the Kullu panIndian dimension while continuing to valorise the local specificity.

Although these different processes of finding a pan-Indian equivalence to local deities may converge, what can be found in informal discussions is the presence of a local discourse, mostly among the local elite, which pinpoints the difference between what is perceived as a Hindutva attitude and what is not. People's awareness of this difference should not be neglected. Indeed, contrary to what happens for a more official and well-known form of history, Hindutva theories on local history in a region like Kullu are not likely to become the object of a public controversial debate. Even someone like Molu Ram Thakur, who explicitly speaks about the danger of a saffronisation of Kullu gods, will hardly express such a concern in his books or articles in these terms.

Another point to be noted is the specific form and meaning that Hindutva resistance takes on in Kullu. Here again the case of Molu Ram Thakur is significant, and shows a way of reacting to Hindutva history-writing other than mobilising academic historians. The debate in Kullu is not about a communalist or a secularistic vision of the past. It is rather about what is perceived to be a non ideological investigation into a possible pan-Indian equivalence of village deities, as opposed to a Hindutva-oriented approach which systematically leads to finding a pan-Indian basis of these village gods, with a view to propagating an ideal of Hindu Rashtra.

\section{Conclusion}

The ABISY project coexists with other attitudes of 'transcending the local' by associating local landscape and mythology with the textual repertory. This may be particularly true in a region like Kullu, where together with the idea that it is situated at the periphery of mainstream Hinduism it is also a suitable 'imagined landscape' for supporting the ABISY rereading of the local past in the light of a 'pan-Indian' textual repertory. The many references to the Himalayas in Sanskrit epic texts, as a favourite place for rishis, heroes or gods to come to, do give a certain consistence to the idea of a reinterpretation of local lore in a 'pan-Indian', Sanskritised framework. The textual reference to the Himalayas has indeed been taken as the starting point by Kullu ABISY leaders for their cultural activity in the area.

The case of Molu Ram mentioned above shows, however, that even issues which in academic circles are considered to be marked by Hindutva, are not specific to Hindutva either, but are likely to be accepted by society at large. One may note, for example, that Molu Ram's book, where he defended the idea of an autochthonous Aryan origin and of a close link between Aryan-Vedic and Indus civilisation, was awarded the "Dr.YS Parmar State Award for Culture" by the Congress Chief Minister of Himachal Pradesh during a solemn ceremony held in Shimla in 2007 (My Himachal, Mar 3rd, 2007).

Another reason why the organisation attracts the attention of local society is, as we have seen, its focus on a "regional project" which is coordinated by people in the locality and whose topic is specific to the place's cultural characteristics. This regional project enables the organisation to be less concerned with defending Hindutva speculations and more active in regional data collection. Moreover, what appears to be specific to ABISY compared with other cultural organisations in the region is its attempt to involve in its project not only literate people or members of the Kullu elite but people from different milieus in rural society. All villagers are called upon here in a form of social and cultural engagement to help collect data on local traditions. Central to the project is indeed the creation of a network, rooted as far as possible in the countryside. People like Hira Lal Thakur or Rajan Seluria, as well as the numerous co-authors of the "rishi book", although from outside Hindutva milieus, are crucial intermediaries for the implementation of the project. Contrary to other local works on regional 
culture, which are the outcome of individual writers, the idea here is to encourage collective works, to edit books written by the largest number of participants possible.

A specificity of ABISY is the systematic attempt to give more visibility to the organisation, by finding occasions to gather people at public meetings. An important celebration in this respect is "History Day", a one-day seminar organised by ABISY once a year in its different local branches and whose topic is chosen by the Central Committee. Every year, ABISY also commemorates the 1857 "Freedom war" and this is even organised at state level. In March 2008, for example, the celebration was inaugurated in Shimla by the Himachal Pradesh Chief Minister P.K. Dhumal. During his inaugural speech he stated that ABISY's role was "to provide the necessary information with regard to the freedom fighters [...] by collecting facts and figures for verification purpose" (Merinews,6 May, 2008). The respectability ABISY is gaining from the media is also shown by an article published in The Hindu in 2006 entitled "Rewrite history with a positive outlook" where the eulogies delivered to the organisation by the Rajastani Home Minister Kataria at the time of the ABISY two-day symposium on "Jainism in Rajasthan" was reported with no further comment. (The Hindu 5 July, 2006)

What is never explicitly found in these articles is any reference to the actual link that ties ABISY to the RSS and to the BJP in its highest spheres. This is in keeping with Jaffrelot's observations mentioned above about the effort made by Sangh Parivar's organisations to tone down their ideological or political affiliations. In actual fact, members are not all BJP and none of them are from RSS either. Although the RSS in Kullu includes quite a number of people regularly going to the shakha and participating in all local ceremonies, the two milieus are relatively separate. Even important members of the Kullu ABISY branch, such as Vidhya Chand and Davendar Singh, are far from being pracharak-like people and do not participate at all in local RSS gatherings.

The case analysed here in fact shows the disparity which may exist between ABISY central leaders' ideological proposals, which tie in with the overall Hindutva effort to 'restructure indigenous religions into a monolithic, uniform religion' (Thapar 1985), and the activities carried out by its intermediates, who, at very different levels, collect detailed ethnographic reports about ritual practices and gods' stories. People like Raja Seluria or Hira Lal Thakur, provide a rich compilation of information concerning a region which is not, in their case, ideologically oriented. Of course, in the mind of the ABISY central leader this is just rough material, which will be used later by specialists to "reveal" or "decode" from the village specificities a more homogenous Hinduism. The paradox, however, is that in order to find out the "Aryan" uniformity of the Kullu culture, ABISY becomes the promoter of a project whose result is to put cultural diversity into writing, at purely village level. As a matter of fact most people in Kullu welcome ABISY projects as an useful way of maintaining their local traditions, and even those who are aware of the unambiguous Hindutva frame in which these collections are made do not publicly criticise their activities and even appreciate the systematic and organised work of collecting data. 


\section{Bibliography}

Berti, D. 2007a. 'Ritual Kingship, Divine Bureaucracy, and Electoral Politics in Kullu', in European Bulletin of Himalayan Research 29/30: 39-61.

2007b. 'Hindu Nationalists and Local History. From Ideology to Local Lore', in Rivista

di Studi Sudasiatici, 1: 5-36.

2006. 'The memory of gods: From a secret autobiography to a nationalistic project, Indian Folklife, 2006, 24: 15-18.

Bhagat R. 1999. 'The tradition of Atthara Kerdu in Kullu people's life', Bhartiya Itihas SankalanYojana Samiti, Kullu, Kullu, Bisy.

Gupta, S.K. 2001. 'Foreword' in R. Arya (ed.), Yug-Yugani Trigarta, pp.1-6, Himachal Pradesh, Bhartiya Itihas Yojna Samiti.

Hansen, T.B. 1999. The Saffron Wave. Democracy and Hindu Nationalism in Modern India, Princeton, Princeton University Press.

Jaffrelot, C. 2005. 'Introduction', in C. Jaffrelot, ed., The Sangh Parivar. A Reader, pp. 1-22. New Delhi, Oxford University Press.

- 2005. The RSS. A Hindu Nationalistic Sect. In C. Jaffrelot ( ed.), The Sangh Parivar. A Reader, pp. 56-102. New Delhi: Oxford University Press.

Kanungo, P. 2003. 'Hindutva's Entry into a 'Hindu Province'. Early Years of RSS in Orissa, Economic and Political Weekly, 2: 3293-3303.

Harneit-Sievers, A., ed. 2002. A Place in the World. New local Historiographics from Africa and South Asia. Leiden: Koninklijke Brill.

Ludden, D. (ed). 2005 [1998]. Making India Hindu. Religion, Community and the Politics of Democracy in India. New Delhi, Oxford University Press.

Malamoud C. 1989. Cuire le monde. Rite et pensée dans l'Inde ancienne, Paris, La Découverte.

Nanda M. 2003. Prophets Facing Backward: Postmodern Critiques of Science and Hindu

Nationalism in India, Rutgers University Press New Brunswick, NJ: Rutgers University,

Puri, W.M.K. 2004. Discovery of Source of Vedic Saraswati in the Himalayas. New Delhi, Akhil Bhartiya Itihas Sankalan Yojana.

Prarthi, L.C. 1970. History and Legend of Kulu, in Kullu Dussehra Committee (ed.), Dussehra Souvenir, pp. 6-7. Kullu, Kullu Dussehra Committee.

Rajagopal, A. 2001. Politics After Television: Religious Nationalism and the Reshaping of the Indian Public. Cambridge, Cambridge University Press.

Shri Baba Saheb Apte smarak samiti (c.1990) Disha Nirdes. New Delhi, Bhartiya Itihas Samkalan Yojna.

Singh, S. 2003. Vedic Culture and its continuity: new paradigm and dimension. New Delhi, Akhil Bhartiya Itihas Sankalan Yojana.

Thakur, M.R. 2000 Vedic Arya aur Himachal. Historical and Research Account [Aryens védiques et Himachal. Histoire et recherches] (New Delhi, H.G. Publication).

Thakur, M. R. 2002. 'Some Cultural Legends and Traditions of the Kulu Valley', in L.S. Thakur, (ed.), Where Mortals and Mountain Gods Meet. Society and Culture in Himachal Pradesh, pp. 321-333. Shimla, Indian Institute of Advanced Study.

Thakur, V. C. 1999, Shabdon men abhivyakta kullu ki dev parampara» [La tradition des dieux de Kullu telle qu'elle s'exprime dans les mots] in, Itihas Divas (Kullu, Akhil Bhartiya Itihas Sankalan Yojana).

Thapar, R. 1985. Syndicated moksha? Seminar 313: 14-22.

. 1999. 'Some Appropriation of the Theory of Aryan Race Relating to the Beginnings of Indian History', in A. Daud (ed.), Invoking the Past. The uses of history in South Asia, pp. 15-35. Delhi, Oxford University Press.

Thakur, S. 2005 Kullu ki rishi parampara, Kullu (H.P.) Bhartiya Itihas Sankalan Samiti. 
Witzel, M.. 2005. 'Indocentrism: Autochthonous visions of ancient India', in Edwin F. Bryant and Laurie L. Patton, The Indo-Aryan controversy: evidence and inference in Indian history, p.341-404. London \& New York: Routledge.

Zavos J. Wyatt A. Hewitt, V. (eds.) 2004. The Politics of Cultural Mobilization in India, Delhi, OUP. 